\title{
Leveraging Stakeholders' knowledge in New Service Development: A dynamic approach
}

\author{
Elena PELLIZZONI \\ School of Management - Politecnico di Milano (Italy) \\ elena.pellizzoni@polimi.it \\ Daniel TRABUCCHI \\ School of Management - Politecnico di Milano (Italy) \\ daniel.trabucchi@polimi.it \\ Federico FRATTINI \\ School of Management - Politecnico di Milano (Italy) \\ federico.frattini@polimi.it \\ Tommaso BUGANZA \\ School of Management - Politecnico di Milano (Italy) \\ tommaso.buganza@polimi.it \\ Anthony DI BENEDETTO \\ Fox School of Business- Temple University (USA) \\ tonyd@temple.edu
}

\section{ABSTRACT}

Purpose: This research aims at shedding lights on the dynamics of involving and sharing knowledge with stakeholders in the process of new service development over time.

Design/methodology/approach: The article is based on a paradigmatic case focused on the development of the digital MBA program by the School of Management of Politecnico di Milano. Primary and secondary data have been largely collected and analyzed, involving multiple stakeholders of the development process.

Findings: This study describes how several stakeholders have been involved during the phase of the New Service Development (NSD) process, showing two variables that ruled their involvement: the level of control exerted by the School on the stakeholders and, the level of flexibility of the stakeholders.

Research limitations/implications: This research offers insights to the understanding of the dynamics of involving and sharing knowledge with multiple-stakeholders in NSD. From a theoretical perspective, it contributes to stakeholder theory linking it with the service management literature, highlighting the role of cyclical fluctuations in the involvement activities.

Practical implications: This research offers insights to managers dealing with the development of new services, offering them a novel view on how various stakeholders may be involved over time, in different moment and in different ways to properly enhance the development process thanks to their knowledge sharing.

Originality/value: This paper contributes to the service management literature emphasizing the role of multiple stakeholders, while providing insights and suggestions to manage the complex relationships created by their involvement and their knowledge.

\section{KEYWORDS}

New Service Development, Digitization, Stakeholder Theory, Stakeholder Involvement, Shared Knowledge; Digital Learning

This is the post-print version of the paper published on Journal of Knowledge Management, please cite as

Pellizzoni, E., Trabucchi, D., Frattini, F., Buganza, T. and Di Benedetto, A. (2020), "Leveraging stakeholders' knowledge in new service development: a dynamic approach", Journal of Knowledge Management, Vol. 24 No. 2, pp. 415-438. https://doi.org/10.1108/JKM-10-2019-0532 


\section{INTRODUCTION}

Innovative companies are increasingly shifting from product-centric approaches to serviceoriented value propositions in order to build and nurture sustainable competitive advantage (Adrodegari \& Saccani, 2017; Falk \& Peng, 2013; Neely, 2008). This phenomenon has been intensified by the widespread digitization that is pushing and making it easier for companies to re-shape their business model around the offering of bundles of integrated digital services (Ardolino et al. 2017; Rust \& Huang, 2014).

These changes in the business models require companies to deeply reshape existing relationships and collaboration patterns in their ecosystem of stakeholders (Vendrell-Herrero et al., 2017). Indeed, service-oriented business model innovation cannot happen in isolation, within the boundaries of the innovation or R\&D department of a company, but through continuous and deep interactions with customers (Siahtiri, 2018; Taghizadeh et al., 2018; Shi et al., 2019) as well as the other relevant stakeholders (Li et al., 2015; Ommen et al., 2016; Jonas \& Roth, 2017). Digitization thus facilitates internal and external connections with stakeholders and knowledge sharing, which have positive impact on innovation performance and competitiveness (Kroh et al., 2018).

As Goduscheit and Faullant (2018) suggest, digitization can be considered one of the main antecedents and enables of business model servitization. However, they highlight that digitization is not a sufficient condition for successful servitization, a well-orchestrated mobilization of resources plays a fundamental role in a successful journey toward servitization (Goduscheit \& Faullant, 2018).

Indeed, stakeholders, such as consumers, suppliers or business partners, can erect barriers toward increased digitization in services, under the effect of skepticism and other psychological and functional barriers (Mani \& Chouk, 2018). Stakeholders' involvement and knowledge in the new service development process can help overcome these resistances (Florén et al., 2018) and to help knowledge sharing (Nikas et al., 2017). For example, both internal and external communications are found to be related to greater services' performances due to an increasing of frontline employee creativity and customer orientation (Siahtiri, 2018).

Researchers have largely documented the positive impact of involving stakeholders and sharing knowledge with them in the innovation process (e.g. Antioco et al., 2008; Driessen and Hillebrand, 2013; Lin and Hsieh; 2014; Goodman et al., 2017). Indeed, the chance to identify and align the strategic priorities and expectations of the various stakeholders involved in the innovation process is a crucial activity (Plaza-Ùbeda et al., 2009). However, scholars have also outlined the challenges and complexities that companies have to face (e.g. Harrison et al., 2010; Jonas \& Roth, 2017). Involving stakeholder and sharing knowledge with them may be expensive (Harrison et al., 2010) and typically requires different resources to be properly orchestrated (e.g., human resources, time and managerial attention) and it can even produce negative consequences on innovation outcomes in the short term (Jonas \& Roth, 2017). 
Moreover, stakeholder involvement and knowledge sharing has been mostly studied at an organization level (Freeman, 1984; Greenley \& Foxall, 1998; Driessen and Hillebrand, 2013), but little is known about how multiple stakeholders and their knowledge may be successfully involved in the New Service Development (NSD) process dynamically, over time (Driessen \& Hillebrand, 2013). Some preliminary attempts to fill this gap can be found in recent research studying the role of stakeholders in NSD (Lin \& Hsieh; 2014; Li et al., 2015; Ommen et al., 2016; Jonas \& Roth, 2017), and focusing on the practices that can be used to manage stakeholders involvement in product development processes (Driessen \& Hillebrand, 2013), but the available knowledge on this topic remains scattered. This article focuses on how multiple stakeholders can be involved to leverage their knowledge throughout the phases of the NSD process. Specifically, our research question is:

How do companies develop new digital services involving and sharing knowledge with multiple stakeholders over time?

The article presents and discusses the results an inductive case study, which illustrates the processes through which the School of Management of Politecnico di Milano (one of the leading International technical universities) designed, developed and delivered an innovative and highly successful digital Executive MBA program (called Flex EMBA), by proactively engaging numerous stakeholders (students, professors, and technology providers).

It represents an interesting case for this research, for two main reasons. First, the intrinsic characteristics of the service may enable the involvement of various types of stakeholders. Second, the digital nature of the service offers several opportunities and challenges from an innovation management perspective, representing a good case to study innovation theories (Nambisan et al., 2017).

This article contributes to stakeholder theory by providing empirical evidence to an academic debate that has been often criticized to be too far from reality (Kaler, 2006, Laplume et al., 2008) and by showing how the concepts established in stakeholder theory can be applied to the service development concept. Furthermore, it adds to service innovation literature by developing a model that focuses on the entire NSD process, and not only on some of its phases (see, e.g., Li et al., 2015) and by offering a dynamic view of the involvement and alignment of different stakeholders and their knowledge leveraging on the opportunities offered by digital technologies (Goduscheit \& Faullant, 2018).

\section{THEORETICAL BACKGROUND}

Three sections constitute the theoretical background: first, a review of the literature on NSD, then a focus on Stakeholder involvement, paying particular attention to the service field. Finally, the research gap is presented introducing the role of digitization regarding NSD and stakeholders' involvement.

\subsection{New Service Development}


Services have raised much attention in management and innovation research, not only for their weight in the economies of industrialized countries, but also because they show several key differences compared with products, such as inseparability, intangibility, perishability and heterogeneity (Lovelock, 1983). Services are based on the interaction between users, providers and physical elements (Johnston, 1999; Menor et al., 2002), and these idiosyncratic characteristics make the development process of new services unique and different from that applied to physical goods and products (De Brentani, 1995).

Scholars developed numerous models describing the anatomy of the new service development process, which is a driver of competitive advantage of service firms (Dotzel et al., 2013). Some of them are comparable to the well-known staged new products process (Cooper, 2001), as they comprise a number of phases undertaken in a chronological order (Donnelly et al., 1995; Alam and Perry, 2002; Melton and Hartline, 2015; Magistretti et al., 2019). Nevertheless, empirical research shows that NSD processes are typically less formalized than new product development processes (Biemans et al., 2016).

Research also shows that the creation, development and delivery of new services usually require a closer involvement and more intense interactions with customers, if compared with product innovation (Jaw et al., 2010). Nevertheless, research on this topic is still in its infancy. Some recent studies focus on how to improve the quality of the participation of stakeholders in NSD projects (e.g., Ommen et al., 2016). However, scholarly research is relatively silent about the mechanisms underlying this phenomenon, leaving practitioners involved in new service development with little or no guidance on how to increase the user involvement in the different phases of the process (Agostini et al., 2016). Although little has been said on how companies can successfully involve stakeholders to leverage their knowledge in an NSD project, research suggests that successful involvement and knowledge-sharing with stakeholders is the result of a trial-and-error and learning process, which takes time to be completed (Driessen \& Hillebrand, 2013), thereby highlighting its dynamic nature.

Research has also shown how the involvement of different stakeholders create interdependences among them, creating the need for indirect and multi-line integration of stakeholders (Jonas \& Roth, 2017). Other studies show that the involvement and knowledge sharing with stakeholders has cyclical fluctuations during the NSD process, since there is a high level of variability in the role played by the different stakeholders over time (Li et al., 2015). Moreover, NSD studies on involving and sharing knowledge with stakeholders focused mainly on the implementation and the commercialization stages of the development process (Jonas \& Roth, 2017), without considering the ideation and the delivery phases.

\subsection{Stakeholder involvement in innovation}

Stakeholders have been defined as "any group or individual who can affect or is affected by the achievement of the organization's objectives" (Freeman, 1984). Stakeholder theory has received increasing interest from organization and management researchers. It has provided a conceptual framework for mapping the main characteristics of different stakeholders, their impact and influence over the decision-making process and the benefits resulting from their 
involvement, their knowledge and their and engagement (Freeman, 1984, Bridoux \& Stoelhorst, 2014; Henisz et al., 2014; Berman et al. 1999; Hsieh, 2009). This extensive research stream has produced theoretical and empirical evidence about the relevance of stakeholder involvement in the new product and service development process.

Involving and sharing knowledge with stakeholders in product innovation is well documented and it represents a key aspect in the recent debate around open innovation. Open innovation emphasizes the relationship between the ability of an organization to access and integrate multiple sources of knowledge coming from its stakeholders and its innovation performance (e.g., Dell'Era et al., 2018; Wu and Hu, 2018; Matricano et al., 2019). A well-developed approach to manage the involvement of stakeholders is a key factor in the success of the product innovation process (Douthwaite et al., 2001; Widèn et al., 2014; Talke \& Hultink, 2010). Research also highlights that involving stakeholders and sharing knowledge in innovation may be expensive and requires significant effort and managerial attention (Harrison et al., 2010). This consideration raises the question of how to manage this involvement and knowledge sharing process, in order to allow companies to adjust and balance the needs and expectations of the different categories of stakeholders along the stages of the development processes (Brown, 2003). Among these categories, research highlights the importance of distinguishing between internal and external stakeholders (Bjørkquist et al., 2015). Considering internal stakeholders, employees and top management play a key role. Employees should be involved in the development of a new product since they own important tacit knowledge that can enhance innovation performance (e.g., Mattsson, 2010; Pellizzoni et al, 2015). The top management team, instead, plays a relevant role in supporting the innovation process, championing it and protecting it from short-term pressures (Smith \& Fischbacher, 2005).

Regarding external stakeholders, suppliers, business partners and final customers play a particularly critical role. The former can potentially play a key role in spotting opportunities for operational improvements, thereby increasing competitiveness and reducing costs and quality issues (Pittaway et al., 2004). Research shows indeed the existence of a positive relationship between the involvement of suppliers in the innovation process and performance (e.g. Patrucco et al, 2017). On the other hand, the involvement of customers in the new product development process is probably the most widely studied form of stakeholder involvement (Carbonell et al. 2012). Customer involvement is defined as the set of interactions established with current or potential customers at various stages during the development process. This is considered to be a critical success factor for product development (Cooper, 2001; Alam, 2006). User involvement in the innovation process has a positive effect both on development time and product quality (Carbonell et al., 2009).

\subsection{News Service Development, Stakeholder involvement and digital opportunities: a research gap}

As mentioned in the introduction, digitization is playing a relevant role in enabling a shift toward servitization (Goduscheit \& Faullant, 2018; Buganza et al., 2019; Magistretti, Dell'Era 
and Messeni Petruzzelli, 2019). The role of digital technologies in service business transformation is undoubted (Ardolino et al., 2017; Adrodegari \& Saccani, 2017; Rust \& Huang, 2014). The digitization leads companies to reshape not only their offering but to move to service-oriented business model (Adrodegari \& Saccari, 2017; Goduscheit \& Faullant, 2018). Servitization, however, often implies having to include an ecosystem of many stakeholders in the development of the innovative service (Kroh et al., 2018). Digitization helps in this process as it facilitates and reinforces collaboration with stakeholders (Nanry et al., 2015; Kroh et al., 2018).

However, digitization may preclude some stakeholders thus their digital capabilities that they cannot have already acquired and embedding (Pagoropoulos et al, 2017). Moreover, digitalization itself is not enough to activate coherently the resources, fundamental for the new service development process (Goduscheit \& Faullant, 2018). These considerations let emerge the research question of this paper: how can companies develop new digital services managing the involvement of multiple stakeholders and their knowledge overtime?

\section{METHODS AND RESEARCH CONTEXT}

To address our research question, we conducted an inductive, longitudinal case study on the development of a new digital service through the involvement and constant interaction with multiple stakeholders, i.e. the Flex EMBA by the School of Management of Politecnico di Milano.

Our case study is an extreme case (Siggelkow, 2007; Yin, 2013) of new service development, in the sense that it was a successful development (as the next section can show, with several follow up editions and various awards) requiring the participation of many different stakeholders throughout all stages of the process. Indeed, by studying such a complex case, it is possible to isolate and recognize the main phenomenon under observation (Pettigrew, 1990; Siggelkow, 2007), elaborating on the theoretical dimensions while also examining and the empirical evidences (Lee et al., 1999). Coherently with the aim of the research, which is process oriented, we leveraged the narrative approach suggested by Langley (1999). We adopted an inductive approach, aiming to clarify the event sequences and separating the overlapping of casual forces. A recursive approach lies at the basis of our theory development. We started by analyzing the case study, to find general patterns and developing theory going through a cycle made of data analysis, emerging theory and existing literature to expand our understanding of the phenomenon (Klein \& Myers, 1999; Yin, 2013).

\subsection{Research setting: The case of the Flex EMBA}

A single case study is suitable to observe unconventional, interesting and extreme organizational settings, where the processes of theoretical interest are clearly observable. These characteristics were evident in the development and delivery phases of a new service at the School of Management of Politecnico di Milano, i.e., a new digital Executive MBA, called Flex EMBA.

To respond to the opportunities and challenges enabled by digital transformation in management education, the School of Management of Politecnico di Milano (SOM) created a 
radically new service involving and sharing knowledge with multiple stakeholders (students, technology providers and faculty professors). SOM was the first business school in Italy and among the few in Europe to offer a digital Executive MBA program taught mainly online. The new program was initiated starting in 2013 , building on the idea of leveraging the flexibility offered by digital technologies to allow students to attend an Executive MBA without the need to reach the SOM campus for traditional, face-to-face classes. Through the combination of different digital learning tools, such as multimedia asynchronous clips, synchronous online classes, synchronous online Q\&A sessions and moderated discussions held through an online forum, students of the Flex EMBA can attend the different courses wherever they are and, for the largest part of the required total effort, they can freely choose when and from where to study and interact with classmates and faculty professors.

The digital learning part of the Flex EMBA is weighted $80 \%$ of the total effort required to students. For the remaining $20 \%$ of the total effort, students meet at the Milan campus of SOM and attend traditional, face-to-face classes, outdoor activities, coaching sessions, executive dinners, and inspirational speeches by top managers and entrepreneurs, designed with the aim to develop soft skills and relational capabilities ${ }^{1}$.

The development of the Flex EMBA has been managed by the Innovation team, composed by two employees of the School of Management and one Professor (which is one of the coauthors of the paper). First intake of the Flex EMBA started in October 2014. At the end of 2019 eleven editions of the program have been launched, involving $400+$ students. In these years, the Flex EMBA has become one of the most important and profitable programs offered by SOM, and it contributed to the $80 \%$ increase in number of students annually enrolled in MBA programs and to the $70 \%$ growth in revenues of MBA and Executive MBA programs. In 2015 AMBA (the Association of MBAs) shortlisted the Flex MBA among the six most innovative MBAs in the world. In 2017, SOM received the EOCCS (EFMD Online Course Certification System) accreditation from EFMD (the European Foundations for Management Development) for the Flex EMBA online courses. The launch of the Flex EMBA has been a success also in terms of students' satisfaction. $74,2 \%$ of the students showed the highest level of satisfaction in the Evaluation survey, reaching also great results in terms of effectiveness (Agasisti et al., 2016). Figure 1 briefly summarizes the timeline of the case, highlighting also the main people involved: the innovation team that take care of the NSD process and manage the stakeholder involvement and the three groups of stakeholders involved: students, faculty and technology providers. The figure also highlights the three phases (Design, Development and Delivery) used to describe the NSD process, which have been defined searching for commonalities in the various NSD processes previously mentioned (e.g.; Cooper, 2001; Donnelly et al., 1995; Alam and Perry, 2002; Melton and Hartline, 2015).

\footnotetext{
${ }^{1}$ By attending the Flex EMBA, students develop the same skills of traditional, face-to-face Executive MBAs. The learning effectiveness has been certified by an independent institution comparing Flex EMBA students and traditional EMBA students.
} 


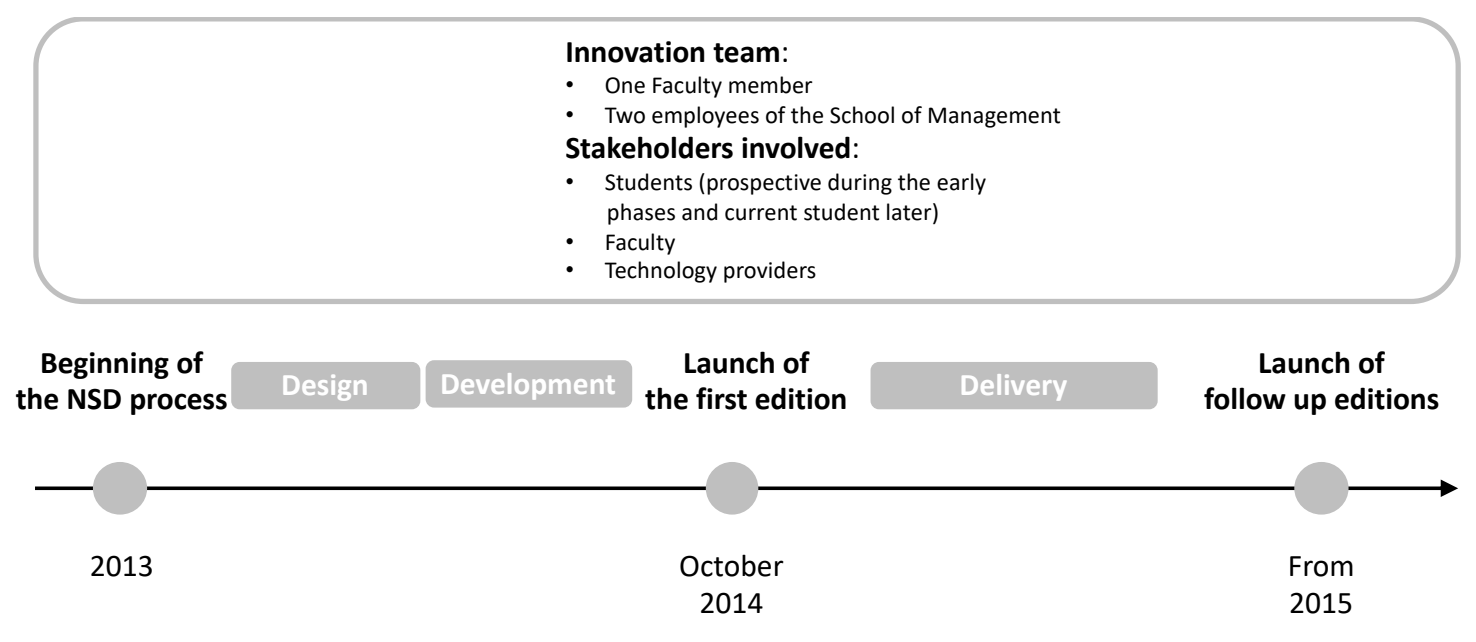

Figure 1: Timeline of the case

\subsection{Data Collection and Analysis}

Data collection lasted roughly five years, since the Flex EMBA inception (in 2013) till the end of the first intake (which ended with student graduation in 2016).

The researchers were all actively involved in conducting interviews and direct observations in various occasions, working together in the data analysis phases to exploit synergies in data triangulation (Eisenhardt, 1989) and to increase the robustness of our analysis (Yin, 2013). Moreover, one of the authors worked on the project development for the entire time span, offering an extensive access to data during this time. Two of the others have been engaged as stakeholders in some of the phases of the development process (in particular, as faculty professors involved in the development and delivery of the program). The last author, who has not been directly involved, brings an external perspective in the analysis of the analysis. The fact that the authors had extensive access to data permitted them to triangulate different and multiple data sources, assuring different perspectives and the reduction of biased viewpoints (Denzin, 1984).

Our database includes semi-structured interviews with various stakeholder groups, a large body of direct observations, and an archive material on the development process, as described in Table 1.

\begin{tabular}{|c|c|}
\hline Data Types & Use in the analysis \\
\hline \multicolumn{2}{|l|}{ Interviews } \\
\hline $\begin{array}{l}\text { First stakeholder group: the Innovation team } \\
\begin{array}{l}\text { - } 5 \text { interviews } \\
\text { - } \quad 7 \text { hours }\end{array}\end{array}$ & $\begin{array}{l}\text { During the first round, questions inquired about the main } \\
\text { phases of the project and the main stakeholders involved. } \\
\text { The team had the chance to create a first draft of the } \\
\text { development process of the entire project, while identify } \\
\text { the other stakeholders. } \\
\text { During the second round, questions inquired about the } \\
\text { relationships among the different stakeholders and the } \\
\text { different phases. }\end{array}$ \\
\hline $\begin{array}{l}\text { Second stakeholder group: students of the first } \\
\text { intake of the Flex EMBA }\end{array}$ & $\begin{array}{l}\text { Questions inquired about their perception during the } \\
\text { service delivery, focusing in particular on how they }\end{array}$ \\
\hline
\end{tabular}




\begin{tabular}{|c|c|}
\hline $\begin{array}{l}-6 \text { interviews } \\
\text { - } 7 \text { hours }\end{array}$ & $\begin{array}{l}\text { interacted with the innovation team and searching for } \\
\text { other latent interactions they had. }\end{array}$ \\
\hline $\begin{array}{l}\text { Third stakeholder group: a group of Professors } \\
\text { involved in the development and delivery of } \\
\text { the first intake of the Flex EMBA. } \\
\begin{array}{l}\text { - } \quad 3 \text { interviews } \\
\text { - } 4 \text { hours }\end{array}\end{array}$ & $\begin{array}{l}\text { Questions inquired about their experience during the } \\
\text { development and the delivery of the service, focusing in } \\
\text { particular on how they interacted with the innovation } \\
\text { team and searching for other latent interactions they had. }\end{array}$ \\
\hline $\begin{array}{l}\text { Fourth stakeholder group: a representative of } \\
\text { the technology provider } \\
\begin{array}{l}\text { - } \quad 2 \text { interviews } \\
\text { - } 3 \text { hours }\end{array}\end{array}$ & $\begin{array}{l}\text { Questions inquired about their experience during the } \\
\text { development and the delivery of the service, focusing in } \\
\text { particular on how they interacted with the innovation } \\
\text { team and searching for other latent interactions they had. }\end{array}$ \\
\hline $\begin{array}{l}\text { Fifth stakeholder group: SOM Top } \\
\text { Management } \\
\begin{array}{ll}\text { - } 2 \text { interviews } \\
\text { - } 2 \text { hours }\end{array}\end{array}$ & $\begin{array}{l}\text { Questions inquired about the strategic goals related to the } \\
\text { project and the top management role during the } \\
\text { development and the delivery process. }\end{array}$ \\
\hline \multicolumn{2}{|l|}{ Field notes } \\
\hline $\begin{array}{l}\text { Focus groups with students } \\
\text { Before the first edition of the Flex EMBA } \\
\text { (with Alumni) - } 12 \text { hours (notes) } \\
\text { During the first edition of the Flex EMBA - } \\
9 \text { hours (notes) } \\
\text { Meetings with } 12 \text { professors before the first } \\
\text { edition } \\
14 \text { hours (notes) } \\
\text { Meetings with the technology provider during } \\
\text { the first edition } \\
52 \text { hours (notes) }\end{array}$ & $\begin{array}{l}\text { The notes have been used to understand the flow of the } \\
\text { events of the development and the delivery of the } \\
\text { services, searching in particular for criticalities and latent } \\
\text { dynamics and triangulating the interviews data. }\end{array}$ \\
\hline \multicolumn{2}{|l|}{ Field data from service delivery } \\
\hline $\begin{array}{l}\text { E-mails } \\
\text { Students during the first edition of the Flex } \\
\text { EMBA (on the content of the program) - } \\
5633 \\
\text { Students during the first edition of the Flex } \\
\text { EMBA (on technical issues about the digital } \\
\text { learning platform) - } 2359 \\
\text { Professors (before the first edition of the } \\
\text { Flex EMBA, during the recording of the } \\
\text { multimedia material) - } 456 \\
\text { Professors (during the delivery of the first } \\
\text { edition of the Flex EMBA) - } 980 \\
\text { Customer satisfaction questionnaires - } 360 \\
\text { questionnaires } \\
\text { Threads in the online forum - } 563 \text { threads } \\
\text { Digital learning tools (Videos) } \\
\text { Clips - } 100 \text { hours } \\
\text { Q\&As - } 43 \text { hours } \\
\text { Live teaching sessions - } 86 \text { hours }\end{array}$ & $\begin{array}{l}\text { The field data have been used to understand the flow of } \\
\text { the events of the development and the delivery of the } \\
\text { services, searching in particular for criticalities and latent } \\
\text { dynamics and triangulating the interviews data. } \\
\text { The videos have been used to align all the researchers on } \\
\text { what the different parts of the service are, having } \\
\text { complete access to what happened during the first edition } \\
\text { of the service. }\end{array}$ \\
\hline
\end{tabular}




\begin{tabular}{|l|l|}
\hline Direct Observations and Actions \\
\hline researcher working in the Innovation team & $\begin{array}{l}\text { Direct observations of the Flex EMBA strategic and } \\
\text { operative dimensions. }\end{array}$ \\
\hline $\begin{array}{l}\text { service development (2 of them filming clips of } \\
\text { one of the modules of the course) and service } \\
\text { delivery } / 2 \text { of them participating in live } \\
\text { sessions, Q\&As and tutoring the students } \\
\text { online) }\end{array}$ & $\begin{array}{l}\text { Direct observations and actions helped the authors team } \\
\text { to have a clear view of what happened during specific } \\
\text { the chance to triangulate information gathered through } \\
\text { other sources, while relying on the external author to } \\
\text { have an unbiased view on the findings. }\end{array}$ \\
\hline $\begin{array}{l}\text { 43 Newspaper articles collected in the MIP } \\
\text { press archive (2014-2017) }\end{array}$ & $\begin{array}{l}\text { Determine press coverage related to have the public } \\
\text { perspective on the service. }\end{array}$ \\
\hline
\end{tabular}

Table 1: Data sources

An inductive and iterative approach has been used to analyze the rich body of data (Miles \& Huberman, 1984; Strauss \& Corbin, 1998). We started coding our field notes into phases, stakeholders and dynamics between them. The last part of the analysis cycle deals with the theorizing process, useful to disambiguate codes, consolidating or deleting them, coherently with our inductive approach (Lee et al., 1999).

\section{FINDINGS}

The following section presents the results of the analysis of the development of the Flex $E M B A$, introducing first the stakeholders involved, their role in the knowledge sharing and then analyzing the three main phases of the process: design, development and delivery.

In order to represent the evolution of the process of involving and sharing knowledge with stakeholders in the three phases, the kind of relationship that the innovation built with a specific stakeholder group is going to be described for each phase.

In particular, we rely on previous research (see, e.g., Greenhalgh and Stones, 2010; Young et al, 2010) which suggests that involving and sharing knowledge with stakeholders can be mapped along four phases: (i) problematization, in which the innovation team searches for other actors who share the same issue; (ii) interest, in which there is an alignment between actors, who share their skills, knowledge or other resources; (iii) enrollment, during which new actors join the network and work together; (iv) mobilization, in which the actors are engaged and fulfill their roles linking with others in the network.

\subsection{Stakeholders}

Throughout the Flex EMBA development process, one of the most critical tasks carried out by the innovation team was to establish and manage the relationships with diverse stakeholders. In the words of the leader of the innovation team: "At the beginning we understood that we were creating something truly radical, challenging traditional paradigms for students, professors and technology providers. We needed to have these stakeholders all on board not only to involve them, but also to leverage their knowledge to understand the best direction to take in the development process for all the parties involved." 
First, the innovation team had to face the challenge of involving prospective students, as future users of the innovative service. The innovation team aimed to involve customers in the development phases. They knew that users' possible disappointment for being involved into a still not fully tested beta version of the service could be counterbalanced by the excitement for playing an active role in the radical innovation process, bringing their knowledge to it. This trade-off emerged clearly from the words of a students during a focus group: "On the one hand we perceive ourselves as pioneers, on the other hand [...] have the chance to contribute to the development of a tailor-made service. This definitely increased for sure our satisfaction".

Faculty professors were the second main stakeholder category involved in the development of the Flex EMBA. The faculty was responsible for the quality of the courses as professors were involved in recording the multimedia clips and in delivering the online live and Q\&A sessions along the duration of the Flex EMBA, but also trying to bring their knowledge in the project. However, many of them were not familiar with the opportunities and challenges of digital learning, and none of them had significant prior experience with this educational approach. The new teaching methods and tools could threaten to them and their lack of commitment would have easily led the project to failure. As noted by one of the members of the innovation team: "Several professors were skeptical about the idea of the Flex EMBA, somehow scared by the innovative nature of this project. We talked with all of them, we listened to their opinions, trying to design a new program by considering their perspectives and ideas".

Finally, the last category of key stakeholders were technology providers. It appeared immediately clear to the innovation team that the digital platform would have been a major source of opportunities (as an enabler of interaction among the students and professors) but also a potential cause of rigidity and source of complexity and issues. The platform was going to be the first contact point that users would evaluate in their digital experience, and therefore it had to be enjoyable and highly user friendly. The technology provider appeared soon as a critical stakeholder for both the first development and the future updates of the service. The involvement of this stakeholder was also complicated by the poor technical knowledge of the team as in the words of the team leader: "Probably we do not have an extensive knowledge either on the opportunities offered by new technologies nor on the panel of potential providers and existing solutions... and surely we do not have time and skills to build this knowledge ourselves"

\subsection{Design}

In the design phase, the innovation team built the concept of the new service. Two main tasks were performed at this phase: (i) pre-design and (ii) design and feasibility.

First, in the pre-design step, the main objective of the innovation team was to retrieve information to understand if and how the new service could create value for students and professors. This multi-stakeholder approach to new service design was a key aspect from the 
beginning of the process because each category of stakeholders could jeopardize the entire service development if not interested in the project. The innovation team decided to focus separately on students and professors.

On the student side, the innovation team organized a series of focus groups with the alumni of the SOM to collect insights on the idea to develop a digital Executive EMBA from former students of the School. During these discussions, students were asked to describe the practical problems and needs that could be addressed through a digital EMBA, such as balancing work commitments and courses activities and reducing or eliminating the time needed to travel to the campus to attend face-to-face classes. As it typically happens in the problematization phase of the involvement process, the focal actor (i.e. The innovation team) was searching for other actors sharing its vision. As an innovation team member recalled: "The insights and problems collected during the focus groups were not particularly breakthrough but I think that the focus groups helped our Alumni to understand the problem that we wanted to solve with the Flex EMBA." He also highlighted that "these initiatives unexpectedly produced strong involvement and word of mouth in the Alumni and prospective student's community". Alumni and prospects "began to talk about our intention to develop a digital Executive MBA, showing curiosity for the new service and motivation to participate in the NSD process". This quotes clearly resembles the dynamics taking place in the interest phase, which entails aligning the different actors to get them on board and to leverage their own skills and perspectives in the development of the new service.

The innovation team adopted a different approach to involve the second category of stakeholders (i.e. professors) because the result to be achieved through this involvement was completely different. The whole range of professors (covering all the topics needed for an MBA program) had to be fully involved in the service development process. As one member of the innovation team said: "Professors are the lifeblood of the entire service, you can have hundreds of students on board, but it's the work of the faculty professors that will determine the success or the failure of the entire project. Having professors who don't believe in the mission of this new service was among the biggest threats for us. Thus, we worked closely with them, trying to bring them on board as much as we could". On top of this, they have a considerable knowledge not only on the topics, but also on the design of a program and on the learning experience of students.

Consequently, the effort put by the innovation team to involve faculty professors was remarkable. It was decided to segment the faculty into two clusters: "Enthusiasts" (the ones willing to embrace the change) and "Neutral and Opponents" (the ones having no or negative attitude towards the change). Fortunately, the enthusiasts were a significant number: 12 out of 27 total professors involved in the Flex EMBA. This segmentation reduced the complexity of the faculty involvement process and allowed the innovation team to quickly complete the problematization and interest phases. 
The innovation team targeted firstly the enthusiasts and particularly those who were considered opinion leaders into the school in order to create momentum and make the cultural innovation process start. "Both categories of professors were aware that digital transformation would lead to change traditional classes with slides and flip boards in something more interactive and enjoyable" explains one member of the innovation team. He continues: "The problem was to explain to the faculties reluctant to change that time had come to change approach to teaching, otherwise it would be too late [...] but once some enthusiastic opinion leaders embraced the project the other followed quite easily". When each of the two categories of professors realized the importance of the issue, even the ones who were initially against the change began to recognize it as inevitable and the discussion about should-we-do-it turned easily into a discussion about how-to-do-it, focusing on opportunities and challenges of the digital shift. Once this happened the innovation team triggered the enrollment phase for the professors by asking the Dean of SOM to meet each professor personally to present the project, the expected results and the level of commitment required to the faculty. Through these mechanisms and the word-of-mouth discussed above, the innovation team ensured that faculty professors were involved and on board.

In the pre-design phase of the process, the technology side of the stakeholder network was not directly targeted or acted upon by the innovation team. It was too early to select either a provider or a solution and the team wanted to keep more doors open for following stages. Moreover, the innovation team lacked the advanced knowledge to interact effectively with technology providers. Thus, the team decided to work together with a technology expert for a preliminary screening of the technological opportunities. The technology expert became the interface of the innovation team towards the technology. By doing so, the innovation team created a bridge between them and the technology side of the stakeholder network. By doing so they reduced the complexity deriving from directly involving and sharing knowledge with several potential technology providers in the service development process. In this phase, the technology expert helped the team in designing the concept of the service, giving knowledge of the technical feasibility of the desired features of the new digital learning platform. For example, he suggested using an app to allow students to watch the clips when they were offline, instead of using only the online platform through a web browser. The technological expert was the first player to push significantly on the usage of digital tools, due to his background and knowledge. This led to a massive reduction of the implementation costs. In this regard, a member of the innovation team admitted: "We are part of a business school, we study the impact and use of digital technologies in business, but in that moment, we needed someone with a technical perspective, someone able to guide us through the different suppliers, helping us understand which, among our requests, were obvious, challenging or even impossible to be implemented".

Moreover, the expert brought to the table the providers' point of view without having them on board, which eventually resulted in a reduced time to complete the service design phase. 
In other words, the technology expert allowed to quickly go through the problematization, and interest phases of the involvement process on the technology side.

The main characteristics of these tasks are summarized Figure 2 and in Table 2.
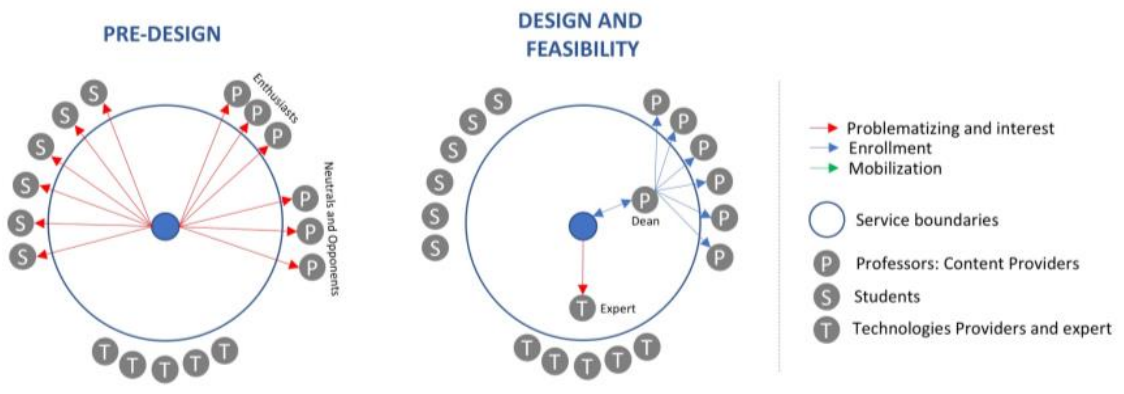

Figure 2: Involvement of stakeholders in the design phase.

\begin{tabular}{|c|c|c|}
\hline Name & Pre-design & Design and feasibility \\
\hline Main objectives & $\begin{array}{l}\text { Collect information about needs, desires and } \\
\text { visions }\end{array}$ & Design of the innovative service \\
\hline $\begin{array}{l}\text { Stakeholders } \\
\text { Involved }\end{array}$ & $\begin{array}{l}\text { 1. Students: } \\
\text { - Business School Alumni } \\
\text { - Prospects } \\
\text { 2. Professors } \\
\text { - Enthusiasts }\end{array}$ & $\begin{array}{l}\text { 1. Professors } \\
\text { - Whole faculty (top down approach): } \\
\text { "Enthusiasts" and "Neutral and } \\
\text { Opponents" } \\
\text { 2. Technology } \\
\text { - Technologies expert }\end{array}$ \\
\hline $\begin{array}{l}\text { Typologies of } \\
\text { involvement }\end{array}$ & $\begin{array}{l}6 \text { focus groups and interviews with students } \\
12 \text { meetings with professors }\end{array}$ & $\begin{array}{l}\text { Top down approach mediated by the Dean in } \\
\text { order to completely engage the whole faculty } \\
\text { Co-design with the Technologies Expert } \\
\text { (Feedback on feasibility) }\end{array}$ \\
\hline $\begin{array}{l}\text { Involvement and } \\
\text { Alignment Phase }\end{array}$ & Awareness (Students and Professors) & $\begin{array}{l}\text { Awareness (Technology expert) } \\
\text { Engagement (Professors) }\end{array}$ \\
\hline Main outputs & $\begin{array}{l}\text { Involvement and word-of-mouth on students } \\
\text { and professors' community }\end{array}$ & $\begin{array}{l}\text { Innovative service idea and feasibility } \\
\text { Formal enrollment of professors in the project }\end{array}$ \\
\hline Timing & \multicolumn{2}{|c|}{6 months } \\
\hline
\end{tabular}

Table 2: The design phase.

\subsection{Development}

After the service design phase, the innovation team focused on the development of the new digital learning platform and on creating the multimedia contents to be accessed through the it. The development phase can be divided into three main steps: platform development, contents and program development and the launch of a demo course.

After the design of the concept of the new service, the innovation team asked the technology expert to mediate the relationship with technology providers. The expert helped to analyze the three platform alternatives available and to select the most appropriate provider. His role was not limited to the enrollment of the technological partner but was also focused on the mobilization of the stakeholder involvement process. The expert played the role of mediator between the innovation team and the technology provider. He knows both the needs of 
faculty professors (the expert was a professor himself in a technical department of Politecnico di Milano) and the potentialities of the technologies (which is his main research and professional area of activity). He facilitated a two-way communication process: on one hand, bringing change requests to the technology provider during the development process, and, on the other, explaining technological constraints to the innovation team. This role was crucial in reducing the complexity of involving and sharing knowledge with the technology stakeholder, giving the innovation team the opportunity to keep working on the professors' enrollment. As noted by the technology expert: "My role was to help the innovation team to focus on the right thing in that moment, taking care and advising them on those decisions that otherwise would have slowed down the entire process".

During the development of the platform, efforts were made to maintain faculty professors aligned with the adjustments that were required from a technical point of view. To maximize the efficiency of the communication process and reduce potential oppositions towards the changes, the innovation team focused mainly on opinion leaders among the enthusiasts' cluster. The aim was to trigger a continuous word-of-mouth activity inside the faculty and kept them involved in the initiative.

After the digital platform was developed and the project entered the content and program development phase, the attention of the innovation team was completely redirected toward professors. Training programs had to be designed to teach them how to produce multimedia material, and clips had to be recorded. Through one-to-one coaching activities, for all the 27 professors involved in the process of recording the multimedia material, the innovation team supported them in developing their own courses. These activities were useful to mobilize the actors, such that they actually fulfill their role in the network of stakeholders. As noted by one member of the innovation team: "The best way to bring someone on board is to talk directly with him, not writing, not imposing, but explaining clearly our motivations, our goals and listening carefully to his own opinions and finally provide him full support to do a great job". The team followed an incremental approach. Recording activities began with the opinion leader sub-group among the enthusiast cluster and only later expanded to the whole faculty. As a team member stated: "We discovered how deep the permeability of the previous informal communication was by speaking with the professors during the recording of the multimedia material. They already knew most of the changes we needed to introduce to the service concept due to technology constrains, therefore the following activities [recording] was easier and faster".

When the contents and program development activities were fully in place, the innovation team moved again back the focus on the student side. They organized a demo course to test and present the Flex EMBA to prospect students. The demo course has been a one-week course delivered to almost 40 potential students interested in attending the Flex EMBA. By showing the entire platform and the courses structure in action, the innovation team validated the new service concept while receiving valuable feedbacks from prospective 
students, increasing their perceived value and moving them into the engagement phase. In this last phase only one professor, which was one of the Enthusiast, has been directly involved in the process to teach in the demo course.

Figure 3 and Table 3 synthetically portraits the stakeholder involvement and knowledge sharing activities conducted during the different steps of the new service development phase.
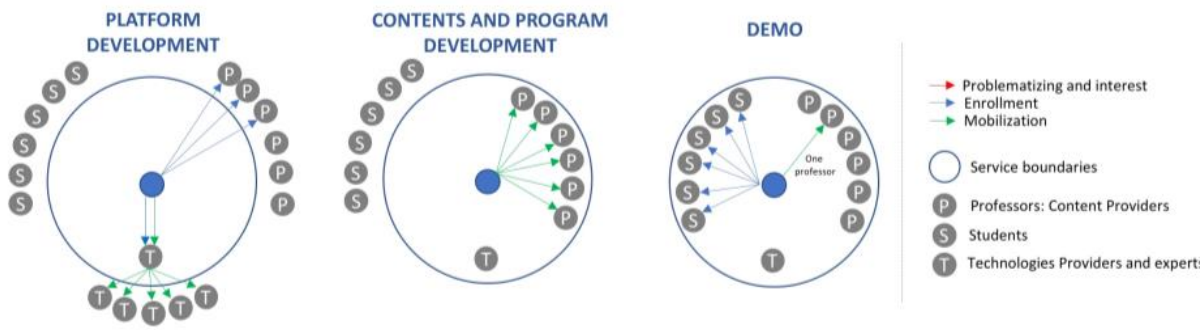

Figure 3: Involvement of stakeholders in the development phase

\begin{tabular}{|c|c|c|c|}
\hline Name & $\begin{array}{c}\text { Platform } \\
\text { Development }\end{array}$ & $\begin{array}{l}\text { Contents and Program } \\
\text { Development }\end{array}$ & Demo \\
\hline Main objectives & $\begin{array}{l}\text { Development of the service } \\
\text { platform and professors' } \\
\text { alignment on changes due to } \\
\text { technology constrains }\end{array}$ & $\begin{array}{l}\text { Development of online } \\
\text { courses (clips recording) } \\
\text { and programs }\end{array}$ & $\begin{array}{l}\text { Show the platform as support for } \\
\text { sales }\end{array}$ \\
\hline Involved Actors & $\begin{array}{l}\text { 1. Technology } \\
\text { - Technology expert as a } \\
\text { mediator } \\
\text { - Technology providers } \\
\text { 2. Professors } \\
\text { - Mainly Opinion leaders } \\
\text { among the Enthusiastic }\end{array}$ & $\begin{array}{l}\text { 1. Professors } \\
\text { - Whole faculty: } \\
\text { "Enthusiasts" and } \\
\begin{array}{ll}\text { "Neutral } & \text { and } \\
\text { Opponents" } & \end{array}\end{array}$ & $\begin{array}{l}\text { 1. Students } \\
\text { - Prospects } \\
\text { 2. Professors } \\
\text { - Just one } \\
\text { 3. Technology } \\
\text { - Technology provider }\end{array}$ \\
\hline $\begin{array}{l}\text { Typologies of } \\
\text { involvement }\end{array}$ & $\begin{array}{l}\text { Top down approach mediated by } \\
\text { the expert in order to facilitate the } \\
\text { relationship with technology } \\
\text { providers } \\
\text { Alignment of professors on new } \\
\text { features and tools }\end{array}$ & $\begin{array}{l}\text { One to one approach to let } \\
\text { professors participation } \\
\text { begin }\end{array}$ & One week of demo course \\
\hline $\begin{array}{l}\text { Involvement and } \\
\text { Alignment Phase }\end{array}$ & $\begin{array}{l}\text { Engagement (Professors) } \\
\text { Participation } \\
\text { provider) }\end{array}$ & Participation (Professors) & $\begin{array}{l}\text { Engagement (Students) } \\
\text { Participation (one Professor and } \\
\text { Technology provider) }\end{array}$ \\
\hline Main outputs & $\begin{array}{l}\text { Service platform and word of } \\
\text { mouth on professors' community }\end{array}$ & Programs and clips & $\begin{array}{l}\text { Feedbacks from the students, } \\
\text { platform test and validation }\end{array}$ \\
\hline Timing & & 12 months & \\
\hline
\end{tabular}

\subsection{Delivery}

Finally, the first edition of the new Flex EMBA was launched on October 2014. The students (33 for the first intake) could access the platform, the asynchronous multimedia clips started to be watched and online synchronous Q\&A and live sessions were delivered through the platform. During this phase, the NSD process continued with the aim to introduce changes to the Flex EMBA in order to adapt it to the needs of the students and prepare the changes to 
be introduced in the second intake of the program, scheduled around six months after the first one.

The first mobilization step made by students was the subscription to the newborn Flex EMBA. Still, the innovation team was aware that this mobilization had to go further than just watching the clips and listening to Q\&As and Live session. The huge amount of feedbacks and the number of change requests came to some extent unexpected, one of the Innovation team members said "From the very first weeks, the class start giving feedbacks, sending emails, using the forum, searching for us with all the digital tools they have...just to talk about what they were living". In this phase the digital nature of the service paid a relevant role, enabling the continuous interaction among the students and the innovation team.

Orchestrating the relationships with the students to collect and discuss all their feedbacks and involving the stakeholders impacted by these changes would have required effort and time beyond the team's capacity. The mechanism used by the innovation team to ease the involvement of the students was to reshape the identity of the network by using some of them as hubs for the requests. This was implemented by proactively selecting the more influencing and active students and by establishing a stronger relationship with them. There were 11 students (out of the 33 enrolled) who were called almost weekly by the innovation team and started to collect and transfer numerous feedback points, comments and proposals generated by the whole cohort.

It is important to highlight how most of the change requests were not feasible due to technological constrains or economic reasons. Therefore, as mentioned by a member of the innovation team: "We began a strong negotiation process with students, making concessions on the easier requests and explaining the motivations of unfeasibility of the others. Some of the non-accepted requests, by the way, were then introduced in the following intakes of the Flex EMBA". For example, slides and studying materials were improved and sent before the clips were made available on the platform, and the format of the evaluation assignments was changed.

The innovation team organized also four focus groups simultaneously involving the abovementioned influential ad active students as well as all the other students, to leverage the influential power of the former to reduce the possible complaints of the latter and to actively involve them in the delivery process. Influential students played a key role in keeping the whole class into the mobilization phase because, through the constant alignment with the innovation team, they already knew what was possible or impossible in the short term and they contributed to drive the expectations of the whole class towards reasonable requests.

During the delivery of the first intake of the Flex EMBA, professors were kept into the mobilization phase as well. The innovation team had the chance to manage personally the relationship with each professor. From one course to the other, the innovation team required different changes to the professors who were going to teach in the following weeks, leveraging the feedbacks previously collected. For example, professors began creating a 
structured template to manage the synchronous Q\&A sessions in a standardized form, starting from challenging questions and recap of the key take-away messages learnt so far, to stimulate the discussion. On the other hand, leveraging on the previous experienced collected by the innovation team, professors were helped to make the synchronous live sessions as engaging and interacting as possible. In this regard, one of the professors asked to have the chance to write on the screen during the synchronous live sessions, and this required the implementation of a technological add-on.

This last example clearly shows also the role of the technology provider in this last step, which remained involved with a critical role. He always remained aligned as well, through weekly meetings. The provider had the chance to take care of technical issues and implementing small changes or add-ons during the delivery.

Figure 4 and Table 4 portrays the stakeholder involvement and knowledge sharing activities conducted by the innovation team during the delivery phase of the new service development process.

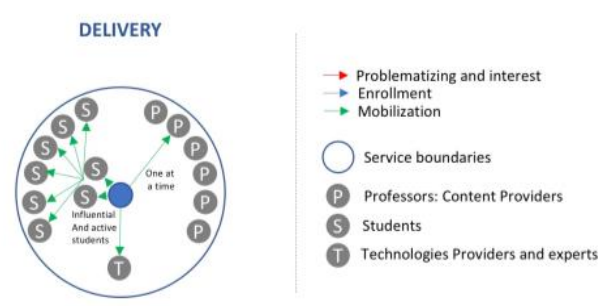

Figure 4: Involvement of stakeholders in the delivery phase.

\begin{tabular}{|c|c|}
\hline Name & Delivery \\
\hline Main objectives & Provide the courses to the students \\
\hline Involved Actors & $\begin{array}{l}\text { 1. Students } \\
\text { - Influential and active students } \\
\text { - All the other students } \\
\text { 2. Professors } \\
\text { - Whole faculty in different periods } \\
\text { 3. Technology } \\
\text { - Technology provider }\end{array}$ \\
\hline $\begin{array}{l}\text { Typologies of } \\
\text { involvement }\end{array}$ & $\begin{array}{l}\text { Focus groups with students, daily feedback from influential and active students (mails and phone } \\
\text { calls) }\end{array}$ \\
\hline $\begin{array}{l}\text { Involvement and } \\
\text { Alignment Phase }\end{array}$ & Participation \\
\hline Main outputs & $\begin{array}{l}\text { Feedbacks from the students, negotiation on opinion leaders' requests based on feasibility and } \\
\text { technology constrains, word of mouth on students' side, developing incremental changes with the } \\
\text { continuous alignment of professors. }\end{array}$ \\
\hline Timing & 7 months \\
\hline
\end{tabular}

Table 4: The delivery phase. 


\section{DISCUSSION}

\subsection{Insights on New Service Development}

The development process of the Flex EMBA shows how the involvement of multiple stakeholders and the chance to leverage their knowledge can contribute to the success of the NSD process by allowing the delivery of successful services through state-of-the-art digital technology (Widèn et al. 2014; Douthwait et al., 2001) and by enhancing the diffusion of the new service after launch (Talke \& Hultink, 2010).

First, our results support the findings of previous research studies. This project supports the idea that innovation, and more specifically service innovation, is not a fully predictable process. Nevertheless, it rather is an erratic process in which different actors are involved, shared their knowledge and participate in different ways and times by spreading their ideas, and searching for allies and cooperating (McLean \& Hassard, 2004; Arnaboldi \& Spiller, 2011). The result of such an approach, though, requires a management that possesses the ability to handle a process marked by a high level of complexity and interactions involving stakeholders, especially when digitalization brings smoothers and wider connections in the ecosystem (Ardolino et al. 2017; Vendrell-Herrero et al., 2017; Siahtiri 2018; Kroh et al., 2018). The innovation team, indeed, devoted the majority of its efforts and time to managing the different stakeholders involved and their knowledge in the process (Harrison et al., 2010). Second, this research project can expand and enhance previous research in the field, unveiling the opportunities provided by the digitalization process (Goduscheit \& Faullant, 2018).

Since previous research pointed out a lack of empirical knowledge on the management of stakeholders in development projects (Kaler, 2006; Driessen \& Hillebrand, 2013), this research enhances the debate proposing the implementation of management practices, aiming to foster the debate on this stream of literature.

It is important to point out how existing research on involving and sharing knowledge with stakeholders in NSD focused only on a specific part of the NSD process - namely the development part (e.g. Jonas \& Roth, 2017) - and often considered users as dormant stakeholders (e.g. Smith \& Fischbacher, 2005). This research focuses on the entire NSD process (design, development and delivery) and shows how users may be involved, not necessary to rely on them to enhance the level of radicalness of the innovation, but to anticipate constraints and to design a service that is going to fit them along the entire process thanks to the knowledge they can bring in the process (relying and merging the suggestions of Agostini et al., 2015 and Jonas \& Roth, 2017).

\subsection{Insights on Stakeholders' involvement}

In this perspective, previous research in the field showed how the same group of stakeholders may evolve over time, changing their typology in a dynamic process (Smith \& Fischbacher, 2005). Building on these concepts, our results shows how the dynamic process in stakeholder management may go much furthered: involving and sharing knowledge with stakeholders may be a dynamic process itself. In fact, the innovation team involved the different stakeholders through the main phases of the innovation process in a fluid way (Callon, 2002), 
moving from Problematization and Interest, to Enrollment and to Mobilization in different moment for each stakeholders' group.

These fluid dynamics are particularly insightful for stakeholder theory, as they highlight how the incremental involvement of different stakeholders may be a way to balance the contrasting interests of the different stakeholders (Hill \& Jones, 1992). Indeed, the empirical results show how the interests may be different between various stakeholders (e.g. users and professors or users and technology providers), and even within the same group of stakeholders (e.g. different kinds of professors, such as the Enthusiasts or the Opponents as previously mentioned) (Table 5). Furthermore, stakeholders may often be resistant to service innovation (Mani \& Chouck, 2018), but a specific kind of involvement and alignment during the process may help reducing their resistance.

\begin{tabular}{|l|c|c|c|c|c|c|}
\multicolumn{1}{|c}{ Pre-design } & $\begin{array}{c}\text { Design and } \\
\text { feasibility }\end{array}$ & $\begin{array}{c}\text { Platform } \\
\text { development } \\
\text { Students }\end{array}$ & $P, I$ & & & Contents and \\
program & Demo & Delivery \\
\hline Professors & $P, I$ & E & & $\mathrm{M}$ & & $\mathrm{M}$ \\
\hline $\begin{array}{l}\text { Technology } \\
\text { Providers }\end{array}$ & & $P, I$ & $\mathrm{E}, \mathrm{M}$ & & \\
\hline
\end{tabular}

Table 5: Multi-stakeholder involvement in NSD [Problematization= P; Interest=I; Enrollment= E; Mobilization=M; M refers to the first phase in which the stakeholder category entered in the mobilized phase]

Relying on these results and on the results of previous literature (e.g. Li et al., 2015), we propose a reference model that may guide in the management of this dynamic relationships in development projects to leverage stakeholders' knowledge (following the suggestions of Kaler, 2006 and Driessen \& Hillebrand, 2013). The model enhances the contribution of the first stage of research, showing how there are some characteristics of the relationship between the management team and the stakeholders that may guide their dynamic involvement and knowledge sharing activities within the NSD process. Figure 5, summarizes the overall model, showing how the involvement of stakeholders vary over time according to two main characteristics: (i) the degree of control on the stakeholder and (ii) their degree of flexibility. The classification of the stakeholders among these two dimensions let emerge a $\mathrm{V}$ shaped involvement path during the development phases of the project. The representation also shows the continuous flow among the three phases. 


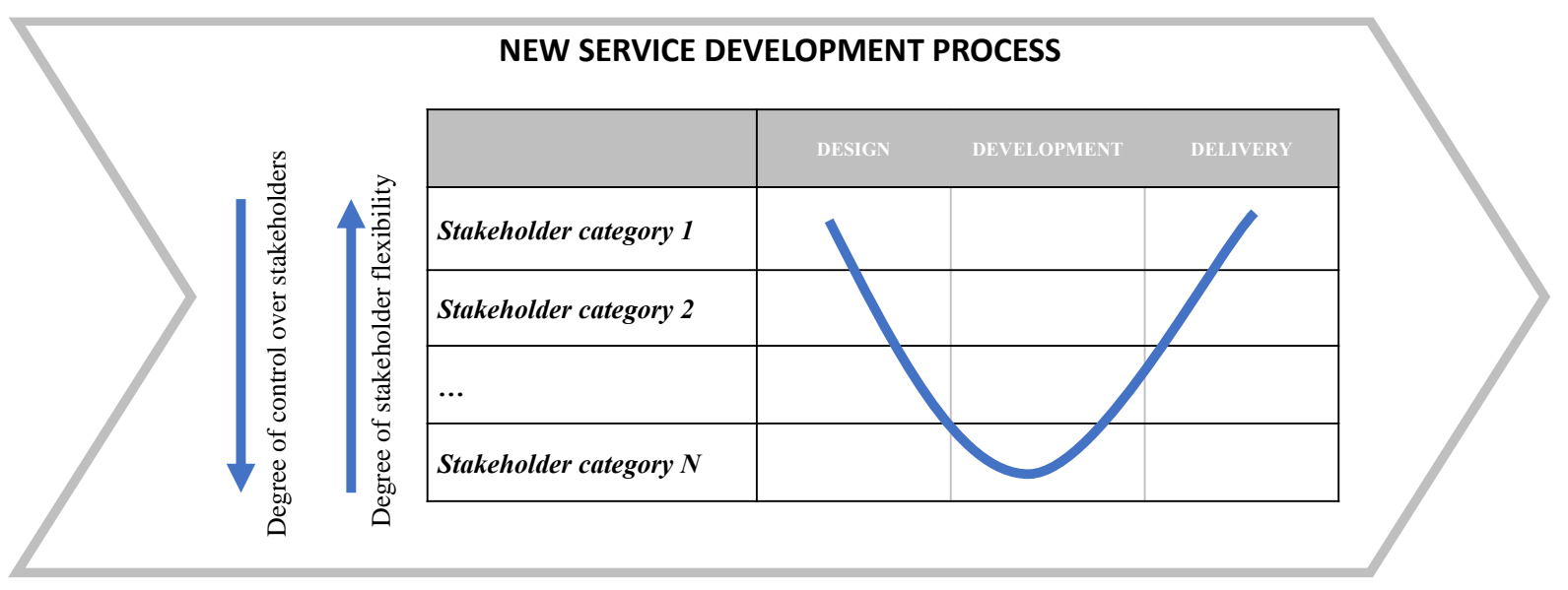

Figure 5: A dynamic model of multi stakeholder involvement

This V-shaped approach is consistent with previous research studies in related fields such as software development (Pressman, 2005), and may represent a reference model for managing multiple stakeholders in development projects. The model suggests that those stakeholders which are very flexible, but with a low degree of the control from the innovation team, should be involved from the very beginning, to exploit the positive influence they may have on the project and leverage their knowledge, as well as in the end, to rely on their flexibility to close the development process leveraging their efforts. On the other hand, those stakeholders which may have a positive impact on the project, but which are less flexible - even though the innovation team may have a good degree of control on them - should be involved in the central development phase, when they need to bring their knowledge in a set of boundaries previously defined. The V-shaped representation suggest the involvement and reinvolvement of the same stakeholder group over time. This suggests the cyclical fluctuation of the involvement of the various stakeholder during the NSD (Li et al., 2015). Indeed, this research suggests the important of understanding when to involve critical stakeholder and eventually when to re-involve them.

Furthermore, previous studies proposed classifications of stakeholders based on their intrinsic characteristics for the organization or for the project, such as considering dormant or dangerous stakeholders relying on their power, urgency and legitimacy (Agle et al., 1999; Smith \& Fischbacher, 2005). The dimensions that emerged in our research - the level of control and the stakeholder's flexibility - suggest a completely different view. Stakeholders may be classified through the kind of relationship that exist between the management team (in our analysis the innovation team) and the stakeholder group, taking decisions on their involvement understanding how much the management team can influence them (the degree of control) and how possible it is to ask them to change (the degree of stakeholder flexibility).

\section{CONCLUSIONS}

This final section presents the contributions of this paper from a theoretical and managerial perspective and finally presents limitations and avenues for future research. 


\subsection{Theoretical contributions}

The importance of service innovation in the global economy cannot be denied, yet it received substantially less attention than product innovation (Adrodegari \& Saccani, 2017; Falk \& Peng, 2013; Neely, 2008). Digitalization has often been considered a key factor in the servitization process (Goduscheit \& Faullant, 2018), that, along with recent trends (such as open innovation, distributed innovation, and ecosystem innovation), are making the innovation process increasingly complex, having a number of internal and external players involved in the process. Nevertheless, little academic research has investigated the growing phenomenon of engaging and managing multiple, diverse stakeholders in new service development applications to exploit their knowledge, making it a research priority especially regarding the how aspect of their involvement (e.g. Kaler, 2006; Driessen and Hillebrand, 2013).

To begin the dialogue on this contemporary phenomenon, this research study uses the theoretical underpinning of Stakeholder Theory to understand the interactive process of multiple stakeholders in a NSD project: the entire development process (design, development and delivery) of a successful digital learning Executive MBA program by the School of Management of Politecnico di Milano: the Flex EMBA. This research study tracks the nature of the interaction among many different stakeholders (including students, professors, and technology providers) throughout the phases of the innovation process followed by an inductive case study analysis.

The results suggest a dynamic model to manage stakeholders during the NSD project, relying on the characteristics of the relationship between the management team and the stakeholders. Our findings offer a contribution that links the two theoretical streams involved: the stakeholder theory and the service literature. This model provides a contribution to stakeholder theory and suggests how multiple stakeholders can be involved and their shared knowledge can be leveraged in NSD.

The main theoretical underpinning of the entire article is stakeholder theory, which is often considered too far from empirical research (Kaler, 2006, Laplume et al., 2008), while this research proposes empirical evidence on the involvement of multiple stakeholders in a real project, through a qualitative approach, which is distinctive in a field developed mainly through quantitative researches (as suggested by Biemans et al., 2016).

Regarding the service literature, few papers have focused on stakeholder management in NSD (few examples are Smith \& Flschbacher, 2005; Li et al., 2015; Jonas \& Roth, 2017) and this research expand these studies in several dimensions. First it focuses on the entire NSD process (as suggested by Li et al., 2015). Moreover, it focuses on the cyclical fluctuations in the degree of involvement of the different stakeholders (pointed out by Li et al., 2015), identifying specific characteristics of the relationship with the stakeholders (namely the level of control on the stakeholder group and their flexibility) to guide these dynamic involvements. Finally, users have not been considered "dormant stakeholders" as in previous studies (e.g. 
Smith and Fischbacher), but relevant stakeholders with a clear role in the overall project, coherently with other researches (e.g. Atuahene-GIma, 1996; Alam \& Perry, 2002), which had a customer perspective more than a multiple-stakeholder one.

\subsection{Implications for managers}

The intrinsic nature of this research project is to provide value both to theory and to practice. Indeed, the describe project lead to the implementation of a successful NSD project. Furthermore, the entire research aims, focusing on how multiple stakeholders may be involved in the development of new services to leverage their knowledge, to have a clear implication for managers.

Considering the above-mentioned limitations, we offer a contribution to the practitioner world showing a successful example of multiple stakeholder involvement, providing a qualitative model that may guide them in taking decisions on other NSD projects, considering the above-mentioned characteristics of the relationship with the stakeholders' groups.

The relevance of these implications is directly related to the increased use of technology to support innovation, and the predominance of collaborative innovation efforts that are bringing to a growing number of stakeholders involved in development processes.

The insights provided in this study suggest some practical considerations that can improve the flow of knowledge between the different stakeholders in a service development context, and thereby yield more efficient innovation results. In other words, this study suggests considering the characteristics of the stakeholder group (such as the degree of control over them and the degree of flexibility) to dynamically involve them in process. This may inform various kind of development process, aiming to capture the greatest value from their involvement.

\subsection{Limitations and future research}

There are limitations to the study which suggest rich directions for future innovation research. Of course, it is not possible to statistically generalize results from an inductive research project nor from an exploratory case study analysis (Yin, 2003). Our aim is to make analytical and theoretical generalizations to the existing body of knowledge regarding stakeholder involvement in the new service development process. It is our intent that the findings will inform future theoretical and empirical studies regarding the process of involving and sharing knowledge with stakeholders. It would be very interesting from a theoretical standpoint to apply a similar research methodology to service development in different industry contexts, such as health care, consulting services, financial services or transportation services. Studies of other service industries could focus on tracking the specific dimensions of decision making identified in this study (level of control and flexibility of involvement) as they evolve throughout the service development process, and gain evidence regarding the generalizability of these dimensions in other industry settings.

\section{REFERENCES}


Adrodegari, F., \& Saccani, N. (2017). Business models for the service transformation of industrial firms. The Service Industries Journal, 37(1), 57-83.

Agasisti, T.; Frattini, F.; Patrucco, A.S.; Pero, M.; Bonfanti, E.; Garavaglia, A.; Petti, L. (2016) The effectiveness of digital tools in post-graduate education: Comparing different use of the flipped classroom approach in MBA programs. Proceedings of the EFMD Higher Education Research Conference, 10th-11th October 2016 Barcelona (Spain) pp.1-19

Agle, B. R., Mitchell, R. K., \& Sonnenfeld, J. A. (1999). Who matters to ceos? an investigation of stakeholder attributes and salience, corpate performance, and ceo values. Academy of Management Journal, 42(5), 507-525.

Agostini, L., Nosella, A., \& Filippini, R. (2016). Users and radical innovation performance: The moderating role of the organisational context. Technology Analysis and Strategic Management, 28(7), 798-810.

Alam, I. (2006). Removing the fuzziness from the fuzzy front-end of service innovations through customer interactions. Industrial Marketing Management, 35(4), 468-480.

Alam, I., \& Perry, C. (2002). A customer-oriented new service development process. Journal of Services Marketing, 16(6), 515-534.

Antioco, M., Moenaert, R. K., Feinberg, R. A., \& Wetzels, M. G. M. (2008). Integrating service and design: The influences of organizational and communication factors on relative product and service characteristics. Journal of the Academy of Marketing Science, 36(4), 501-521.

Ardolino, M., Rapaccini, M., Saccani, N., Gaiardelli, P., Crespi, G., \& Ruggeri, C. (2017). The role of digital technologies for the service transformation of industrial companies. International Journal of Production Research, 56(6), 2116-2132.

Arnaboldi, M., \& Spiller, N. (2011). Actor-network theory and stakeholder collaboration: The case of cultural districts. Tourism Management, 32(3), 641-654.

Berman, S. L., Wicks, A. C., Kotha, S., \& Jones, T. M. (1999). Does stakeholder orientation matter? the relationship between stakeholder management models and firm financial performance. Academy of Management Journal, 42(5), 488-506.

Bican, P.M., Guderian, C.C. and Ringbeck, A. (2017), "Managing knowledge in open innovation processes: an intellectual property perspective", Journal of Knowledge Management, Vol. 21, No. 6, pp. 1384-1405.

Biemans, W. G., Griffin, A., \& Moenaert, R. K. (2016). New service development: How the field developed, its current status and recommendations for moving the field forward. Journal of Product Innovation Management, 33(4), 382-397.

Bjørkquist, C., Ramsdal, H., \& Ramsdal, K. (2015). User participation and stakeholder involvement in health care innovation - does it matter? European Journal of Innovation Management, 18(1), 2-18. doi:10.1108/EJIM-08-2013-0081

Bridoux, F., \& Stoelhorst, J. (2014). Microfoundations for stakeholder theory: Managing stakeholders with heterogeneous motives. Strategic Management Journal, 35(1), 107125. 
Brown, M. M. (2003). Technology diffusion and the "knowledge barrier" the dilemma of stakeholder participation. Public Performance \& Management Review, 26(4), 345-359.

Buganza, T., Trabucchi, D., \& Pellizzoni, E. (2019). Limitless personalisation: the role of Big Data in unveiling service opportunities. Technology Analysis \& Strategic Management, 113.

Callon, M. (2002). From science as an economic activity to socioeconomics of scientific research: The dynamics of emergent and consolidated techno-economic networks. In P. Morowski, \& E. -. Sent (Eds.), Essays in the economics of science (Science Bought and Sold ed., pp. 277-317) University of Chicago Press, Chicago, IL.

Carbonell, P., Rodríguez-Escudero, A. I., \& Pujari, D. (2009). Customer involvement in new service development: An examination of antecedents and outcomes. Journal of Product Innovation Management, 26(5), 536-550.

Carbonell, P., Rodriguez-Escudero, A. I., \& Pujari, D. (2012). Performance effects of involving lead users and close customers in new service development. Journal of Services Marketing, 26(7), 497-509.

Cooper, R. G. (2001). Winning at new products. accelerating the process from idea to launch. Cambridge, MA: Perseus.

De Brentani, U. (1995). New industrial service development: Scenarios for success and failure. Journal of Business Research 32(2): 93-103.

Dell'Era, C., Magistretti, S., \& Verganti, R. (2018). Exploring collaborative practices between SMEs and designers in the Italian furniture industry. Researching Open Innovation in SMEs, 307-345.

Denzin, Norman K. 1984. The Research Act: A Theoretical Introduction to Sociological Methods. Transaction publishers.

Donnelly, J.H., L.L. Berry, and T.W. Thompson. (1985). Marketing financial services: a strategic vision: Dow Jones-Irwin.

Dotzel, T., V. Shankar, and L.L. Berry. (2013). Service innovativeness and firm value. Journal of Marketing Research 50(2): 259-276.

Douthwaite, B., Keatinge, J. D. H., \& Park, J. R. (2001). Why promising technologies fail: The neglected role of user innovation during adoption. Research Policy, 30(5), 819-836. doi:10.1016/S0048-7333(00)00124-4

Driessen, P. H., \& Hillebrand, B. (2013). Integrating multiple stakeholder issues in new product development: An exploration. Journal of Product Innovation Management, 30(2), 364379.

Eisenhardt, K. M. (1989). Building theories from case study research. Academy of Management Review, 14(4), 532-550.

Falk, M., \& Peng, F. (2013). The increasing service intensity of european manufacturing. The Service Industries Journal, 33(15-16), 1686-1706.

Florén, H., Frishammar, J., Parida, V., \& Wincent, J. (2018). Critical success factors in early new product development: a review and a conceptual model. International Entrepreneurship and Management Journal, 14(2), 411-427. 
Freeman, R. E. (1984). Strategic management:A stakeholder approach. Boston: Pitman.

Goduscheit, C. R., \& Faullant, R. (2018). Paths toward radical service innovation in manufacturing Companies-A Service-Dominant logic perspective. Journal of Product Innovation Management, 35(5), 701-719.

Goodman, J., Korsunova, A., \& Halme, M. (2017). Our collaborative future: Activities and roles of stakeholders in sustainability-oriented innovation. Business Strategy and the Environment, 26(6), 731-753.

Greenhalgh, T., \& Stones, R. (2010). Theorising big IT programmes in healthcare: Strong structuration theory meets actor-network theory. Social Science and Medicine, 70(9), 1285-1294.

Greenley, G. E., \& Foxall, G. R. (1998). External moderation of associations among stakeholder orientations and company performance. International Journal of Research in Marketing, 15(1), 51-69.

Harrison, J. S., Bosse, D. A., \& Phillips, R. A. (2010). Managing for stakeholders, stakeholder utility functions, and competitive advantage. Strategic Management Journal, 31(1), 5874. doi:10.1002/smj.801

Henisz, W. J., Dorobantu, S., \& Nartey, L. J. (2014). Spinning gold: The financial returns to stakeholder engagement. Strategic Management Journal, 35(12), 1727-1748.

Hill, C. W., \& Jones, T. M. (1992). Stakeholder-agency theory. Journal of Management Studies, 29(2), 131-154.

Hsieh, M.H. (2009), "Human centric knowledge seeking strategies: a stakeholder perspective", Journal of Knowledge Management, Vol. 13, No. 4, pp. 115-133.

Jaw, C., Lo, J. -., \& Lin, Y. -. (2010). The determinants of new service development: Service characteristics, market orientation, and actualizing innovation effort. Technovation, 30(4), 265-277.

Johnston, R. (1999). Service operations management: Return to roots. International Journal of Operations and Production Management 19(2): 104-124.

Jonas, J. M., \& Roth, A. (2017). Stakeholder integration in service innovation-an exploratory case study in the healthcare industry. International Journal of Technology Management, 73(1-3), 91-113.

Kaler, J. (2006). Evaluating stakeholder theory. Journal of Business Ethics, 69(3), 249-268.

Klein, H. K., \& Myers, M. D. (1999). A set of principles for conducting and evaluating interpretive field studies in information systems. MIS Quarterly,67-93.

Kroh, J., Luetjen, H., Globocnik, D., \& Schultz, C. (2018). Use and efficacy of information technology in innovation processes: The specific role of servitization. Journal of Product Innovation Management, 35(5), 720-741.

Langley, A. (1999). Strategies for theorizing from process data. Academy of Management Review, 24, 691-710

Laplume, A. O., Sonpar, K., \& Litz, R. A. (2008). Stakeholder theory: Reviewing a theory that moves us. Journal of Management, 34(6), 1152-1189. 
Lee, T. W., Mitchell, T. R., \& Sablynski, C. J. (1999). Qualitative research in organizational and vocational psychology, 1979-1999. Journal of Vocational Behavior, 55(2), 161-187.

Li, J. H., Xu, H. Y., \& Lin, L. (2015). Stakeholder management of new service development: An exploratory case study in chinese financial sector. International Journal of Technology, Policy and Management, 15(2), 113-127.

Lin, F. R., \& Hsieh, P. S. (2014). Analyzing the sustainability of a newly developed service: An activity theory perspective. Technovation, 34(2), 113-125.

Lovelock, C.H., (1983). Classifying services to gain strategic marketing insights. The Journal of Marketing 47: 9-20.

Magistretti, S., Dell'Era, C., \& Petruzzelli, A. M. (2019). How intelligent is Watson? Enabling digital transformation through artificial intelligence. Business Horizons, 62(6), 819-829.

Magistretti, S., Trabucchi, D., Dell'Era, C., \& Buganza, T. (2019). A New Path Toward a Hybrid Model: Insights from PwC's Italian Experience Centre. Research-Technology Management, 62(5), 30-37.

Mani, Z., \& Chouk, I. (2018). Consumer resistance to innovation in services: Challenges and barriers in the internet of things era. Journal of Product Innovation Management, 35(5), 780-807.

Matricano, D., Candelo, E., Sorrentino, M. and Martínez-Martínez, A. (2019), "Absorbing inbound knowledge within open innovation processes. The case of Fiat Chrysler Automobiles", Journal of Knowledge Management, Vol. 23, No. 4, pp. 786-807.

Mattsson, J. (2010). Developing a strategic abstraction tool for service innovation. Journal of Strategic Marketing, 18(2), 133-144.

McLean, C., \& Hassard, J. (2004). Symmetrical absence/symmetrical absurdity: Critical notes on the production of actor-network accounts. Journal of Management Studies, 41(3), 493-519.

Melton, H., and M.D. Hartline. (2015). Customer and employee co-creation of radical service innovations. Journal of Services Marketing 29(2): 112-123.

Menor, L.J., M.V. Tatikonda, and S.E. Sampson. (2002). New service development: Areas for exploitation and exploration. Journal of Operations Management 20(2): 135-157.

Miles, M. B., \& Huberman, A. M. (1984). Drawing valid meaning from qualitative data: Toward a shared craft. Educational Researcher, 13(5), 20-30.

Mitchell, R. K., Agle, B. R., \& Wood, D. J. (1997). Toward a theory of stakeholder identification and salience: Defining the principle of who and what really counts. Academy of Management Review, 22(4), 853-886.

Nambisan, S., Lyytinen, K., Majchrzak, A., \& Song, M. (2017). Digital Innovation Management: Reinventing innovation management research in a digital world. MIS Quarterly, 41(1).

Nanry, J., Narayanan, S., Rassey, L., (2015). Digitizing the value chain. McKinsey Q.

Neely, A. (2008). Exploring the financial consequences of the servitization of manufacturing. Operations Management Research, 1(2), 103-118.

Nikas, A., Doukas, H., Lieu, J., Alvarez Tinoco, R., Charisopoulos, V. and van der Gaast, W. (2017), "Managing stakeholder knowledge for the evaluation of innovation systems in 
the face of climate change", Journal of Knowledge Management, Vol. 21, No. 5, pp. 1013-1034.

Ommen, N. O., Blut, M., Backhaus, C., \& Woisetschläger, D. M. (2016). Toward a better understanding of stakeholder participation in the service innovation process: More than one path to success. Journal of Business Research, 69(7), 2409-2416.

Pagoropoulos, A., Maier, A., \& McAloone, T. C. (2017). Assessing transformational change from institutionalising digital capabilities on implementation and development of Product-Service Systems: Learnings from the maritime industry. Journal of Cleaner Production, 166, 369-380.

Patrucco, A. S., Luzzini, D., \& Ronchi, S. (2017). Achieving innovation through supplier collaboration: the role of the purchasing interface. Business Process Management Journal, 23(6), 1270-1289.

Pellizzoni, E., Buganza, T., \& Colombo, G. (2015). Motivation orientations in innovation contests: Why people participate. International Journal of Innovation Management, 19(04), 1550033.

Pettigrew, A. M. (1990). Longitudinal field research on change: Theory and practice. Organization Science, 1(3), 267-292.

Pittaway, L., Robertson, M., Munir, K., Denyer, D., \& Neely, A. (2004). Networking and innovation: A systematic review of the evidence. International Journal of Management Reviews, 5(3-4), 137-168.

Plaza-Úbeda, J. A., Burgos-Jiménez, J., Vazquez, D. A., \& Liston-Heyes, C. (2009). The 'win-win' paradigm and stakeholder integration. Business Strategy and the Environment, 18(8), 487-499. doi:10.1002/bse.593

Pressman, R. S. (2005). Software engineering: A practitioner's approach Palgrave Macmillan.

Rust, R. T., \& Huang, M. (2014). The service revolution and the transformation of marketing science. Marketing Science, 33(2), 206-221.

Shi, X., Zhang, Q. and Zheng, Z. (2019), "The double-edged sword of external search in collaboration networks: embeddedness in knowledge networks as moderators", Journal of Knowledge Management, .

Siahtiri, V. (2018). Innovation at the service encounter in knowledge intensive business services: Antecedents and boundary conditions. Journal of Product Innovation Management, 35(5), 742-762.

Siggelkow, N. (2007). Persuasion with case studies. Academy of Management Journal, 50(1), 20-24.

Smith, A. M., \& Fischbacher, M. (2005). New service development: A stakeholder perspective. European Journal of Marketing, 39(9/10), 1025-1048.

Strauss, A., \& Corbin, J. (1998). Basics of qualitative research: Procedures and techniques for developing grounded theory.

Taghizadeh, S.K., Rahman, S.A. and Hossain, M.M. (2018), "Knowledge from customer, for customer or about customer: which triggers innovation capability the most?", Journal of Knowledge Management, Vol. 22, No. 1, pp. 162-182. 
Taghizadeh, S.K., Rahman, S.A. and Hossain, M.M. (2018), "Knowledge from customer, for customer or about customer: which triggers innovation capability the most?", Journal of Knowledge Management, Vol. 22, No. 1, pp. 162-182.

Talke, K., \& Hultink, E. J. (2010). Managing diffusion barriers when launching new products. Journal of Product Innovation Management, 27(4), 537-553.

Vendrell-Herrero, F., Bustinza, O. F., Parry, G., \& Georgantzis, N. (2017). Servitization, digitization and supply chain interdependency. Industrial Marketing Management, 60, 69-81.

Widén, K., Olander, S., \& Atkin, B. (2014). Links between successful innovation diffusion and stakeholder engagement. Journal of Management in Engineering, 30(5)

$\mathrm{Wu}, \mathrm{I}$. and Hu, Y. (2018), "Open innovation based knowledge management implementation: a mediating role of knowledge management design", Journal of Knowledge Management, Vol. 22, No. 8, pp. 1736-1756.

Yin, R. K. (2013). Case study research: Design and methods. Sage publications. 